
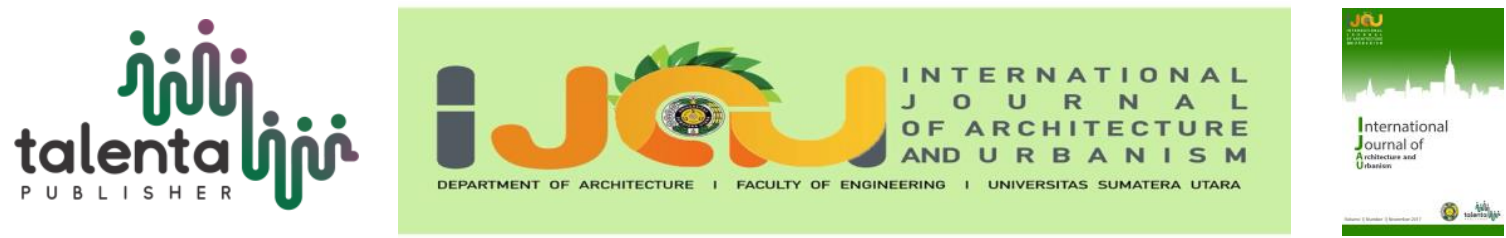

\title{
Designing of Samosir Ulos Weaving Craft Center by Metaphorical Architecture
}

\author{
Imam Faisal Pane ${ }^{1^{*}}$, Rofi Bintang Mishael ${ }^{1}$ \\ ${ }^{1}$ Architecture Departement, Faculty of Engineering, Universitas Sumatera Utara, Medan, Indonesia
}

\begin{abstract}
Ulos weaving craft is one of the most famous cultures of the Batak tribe. And the Lumban Suhi-Suhi Toruan Village in Samosir District is one of the traditional villages that still maintain customs and native Batak Toba village. The residents of Lumban Suhi-Suhi Toruan village especially the women working as Ulos weavers, and Ulos from Lumban Suhi-Suhi Toruan village, have been quite well-known to foreign countries, however, at present, the number of weavers has diminished, and many types of Ulos cloth have become extinct because of losing its craftsman. The Samosir Ulos Weaving Craft Center is present as a tool that can maintain the Ulos handicrafts of the local community and also empower the community as a place to produce various types of Ulos. The research methodology starts by collecting data, literature studies, Surveys to research locations and also design problem-solving. From the research process by the existing one, this building use metaphor architecture theme as its concept. The choosing of the metaphor theme in the building is considered to be able to describe the function and also introduce the culture of Ulos to the community. The Bintang Maratur Ulos pattern and the Mangulosi ceremony is forming the metaphor concept of the building. With the research and design of the Ulos Samosir weaving center, this can be a consideration for the Samosir district government or local community leaders to make this facility.
\end{abstract}

Keyword: craft center, metaphor architecture, ulos.

\section{Introduction}

Indonesia is a country that has many customs and cultures, especially in North Sumatra. North Sumatra has many people from various ethnicities and cultures. Batak is one of the tribes in Indonesia, and Ulos weaving is one of its cultures. The presence of Ulos is always present to everyone who attends the traditional events, like during the Lahran, marriage, and other ceremonies. An Ulos weaver certainly has skills and abilities in the field of Ulos weaving or commonly called Martonun Ulos by the Batak Toba tribe. Ulos weavers know what kinds of Ulos, functions, materials of manufacture, tools used in weaving, and also the true meaning of an Ulos and the weaving process. According to Sianipar (2017), Currently Ulos weavers are decreasing every year and are experiencing a dilemma because they have to meet economic needs, many weavers in Samosir area who now prefer to produce ulos Karo than Toba Batak

\footnotetext{
*Corresponding author at : Departement of Architecture, faculty of Engineering, Universitas Sumatera Utara,

Jalan Perpustakaan, Building J07, Medan 20155, Indonesia

E-mail address: imamfpane@gmail.com
} 
Ulos which are more popular and easier to make, so that it earns money faster, compared to the Batak Toba Ulos, the process is complicated and people use it only in certain events. The location of Ulos Weaving and Culture Center is located in Samosir Regency, precisely in Pangururan sub-district, Lumban Village, Suhi-Suhi Toruan, which is famous for its Ulos village, where all the residents of this village, especially the women, are Toba Batak-style Ulos craftsmen who still use traditional way (Figure 1).

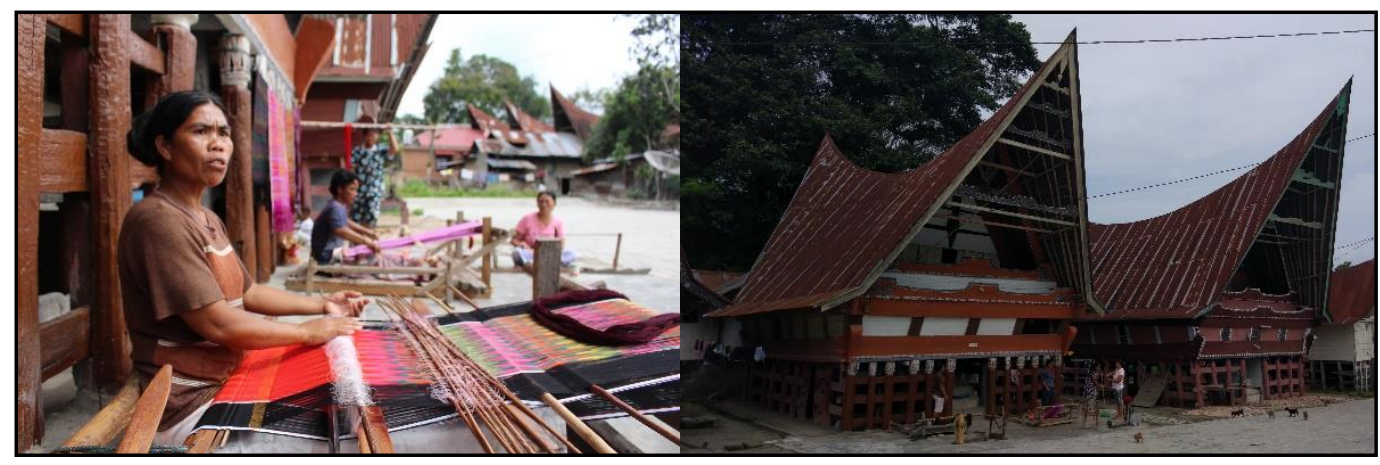

Figure 1. Ulos weaving tradition in Lumban Suhi-Suhi Toruan Village

\section{Literature Study}

Samosir Ulos Weaving Craft Centre is a staple of the Batak tribal handicrafts and is located in the Samosir district which is also a place to buy and sell Ulos weaving exhibitions.

Ulos is a woven fabric, generally has a width of about $50-150 \mathrm{~cm}$ and a length of $150-220 \mathrm{~cm}$ and is made of cotton fiber yarn. Ulos is clothing in the form of cloth woven by Batak women with various patterns and sells in some clothing market. According to the Batak concept, Ulos is an action infused with religious and magical qualities. In Batak society belief, Ulos is considered an object blessed by supernatural powers [1].

The design location is in Pangururan Sub-district, Lumban Suhi-Suhi Toruan Village, Samosir Regency, North Sumatra Province, Indonesia. This sub-district administratively consists of 9 Sub-Districts and 106 Villages.

The design of Ulos Samosir Weaving Craft Center will use "Metaphoric Architecture" as its theme. The metaphor is the use of words or groups of words not with their true meaning, but as paintings based on equality or comparison [2]. Aristotle defining the metaphor as "Intuitive Abstraction of uniqueness in diversity" [3]. The general function of metaphor is influencing many objects, including architecture. For instance, from Modernism's conviction of form follows function to Minimalism's less is more approach; these architectural dictums have become synonymous with the Modern Movement [4].

According to James C. Snyder and Anthony J. Cattanesse in "Introduction of architecture" metaphor identifies patterns that may occur from parallel relationships by looking at their 
abstractness, in contrast to analogies that look literally [5]. And according to Charles Jenks in "The Language of Post Modern Architecture" defines metaphor as a code that is captured at a time by the observer of an object by relying on other objects and how to see a building as something else because of the similarity [6]. The building of Ulos Samosir Weaving Crafts Center takes the application of the Metaphor theme with the tangible metaphor category, which applies the physical form of Ulos cloth. According to Anthony C. Antoniades (1990) in the "Poetic of Architecture," there are three categories of metaphors, namely tangible metaphor, intangible metaphor, and combined metaphor [7]. And the application of tangible metaphor design of the building will interpret the Sadum Ulos ornament which is brightly colored and has a horizontal and rhombic and also a star-shaped wave ornament from the Maros Star Ulos motile [8]. Furthermore, in addition to the formation of Ulos ornaments, the intangible metaphor will symbolize the event of bridal Mangulosi on the Batak wedding ceremony to the concept of the building. Mangulosi is the ceremony where the Batak bride and groom wore the Ulos.

\section{Methodology}

According to the criteria that have been determined from several considerations, namely the extent, accessibility, achievement of existing functions, atmosphere, level of congestion, and some regulations, such as Samosir Regency's RDTR will consider the design location.

There are two design methods in architecture, namely the traditional one called black box and the rational called the glass box method [3]. The design of the center of Ulos Samosir Weaving Craft Center will use the glass box method, which is a more rational one in which is easier to trace each stage and process, which means that each process is planned carefully by the stages of the architectural design. The type of data used in the design consists of primary data and secondary data obtained through the Observation and Literature Study processes.

\section{Result and Discussion}

Location of Weaving Ulos Samosir Craft Center is in Samosir District, Pangururan Sub-District, Lumban Suhi-Suhi Toruan Village, precisely adjacent to the Huta Raja Ulos Village which is one of the villages in the Samosir area which is famous for its residents who work as Ulos weavers and also their settlement patterns which is filled with Bolon Houses that have existed since the time of their ancestors. This location of this sub-district at $20 \mathrm{o} 32$ ' $-20 \mathrm{o} 45^{\prime}$ ' North Latitude and 980o 42 '- 980o 47 East Longitude above the height of 50.37 meters above sea levels. And this sub-district has a population of 30,648 people and a total area of 121,43 square kilometers [9].

The site is in Pangururan Subdistrict, Samosir Regency, precisely in Kampung Ulos Huta Raja. The choosing of this site, because it is one of the cultural tourism areas in Samosir Regency, the beauty of Kampung Huta Raja and Ulos by the craftsmen of Ulos weaving is well known 
internationally. According to the Pangururan District RDTR 2017-2033, the Kampung Huta Raja area is planned to be one of the community tourism destinations. Therefore, the selection of Kampung Huta Raja as the design location becomes the potential of the site itself. The view and orientation of the site location border Toba Lake and a traditional village called Lumban Suhi-Suhi Village (Figure 2).

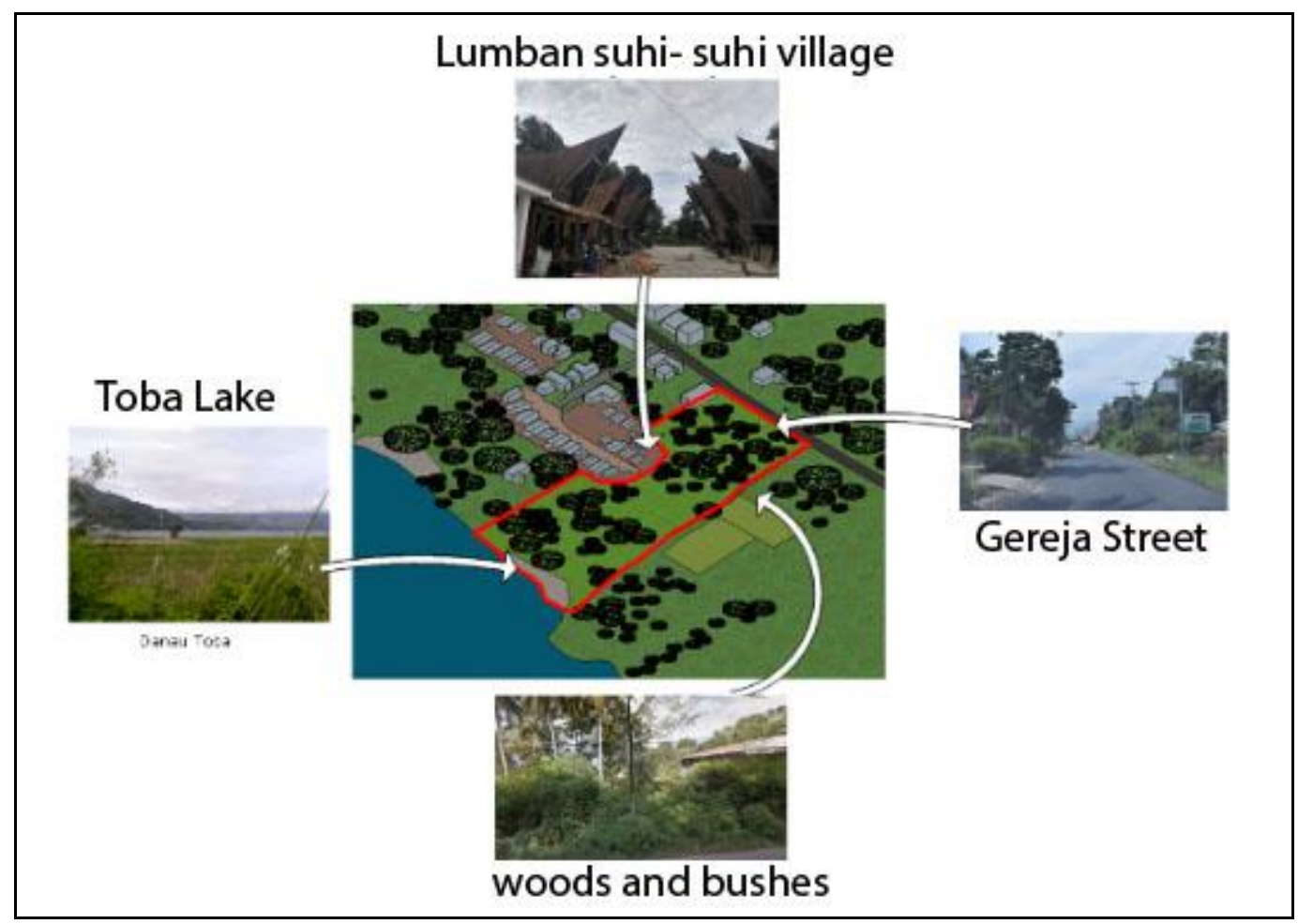

Figure 2. View and Orientation of The Design Area

Lumban Village Suhi-Suhi Toruan is one of the large traditional villages in the Pangururan area. The Bolon houses in this village are the original Bolon Houses, which were dug up by the ancestors of the villagers, and most of it is still well maintained, although there are some houses that use masonry walls to the back of the house to expand the house. In addition to many Bolon Houses, one of the uniqueness of this village is that there are several historical relics found in the central part of this area, namely the tomb of the first king of the village, there are also ricemortar inheritance of the villagers, Therefore, the uniqueness of this village through tradition and architecture traditionally is one of the main potential design sites. 
And based on RDTR ${ }^{*}$ of the Pangururan Sub-District is determined how to build a building based on its zoning. And based on the location of the design that is in the W-4 Zone or Community Tourism Zone, and this zone set some regulation for the shape and façade of the building in Pangururan Sub-district, such as the decoration for carvings, the roof shape and the room organization (Figure 3).

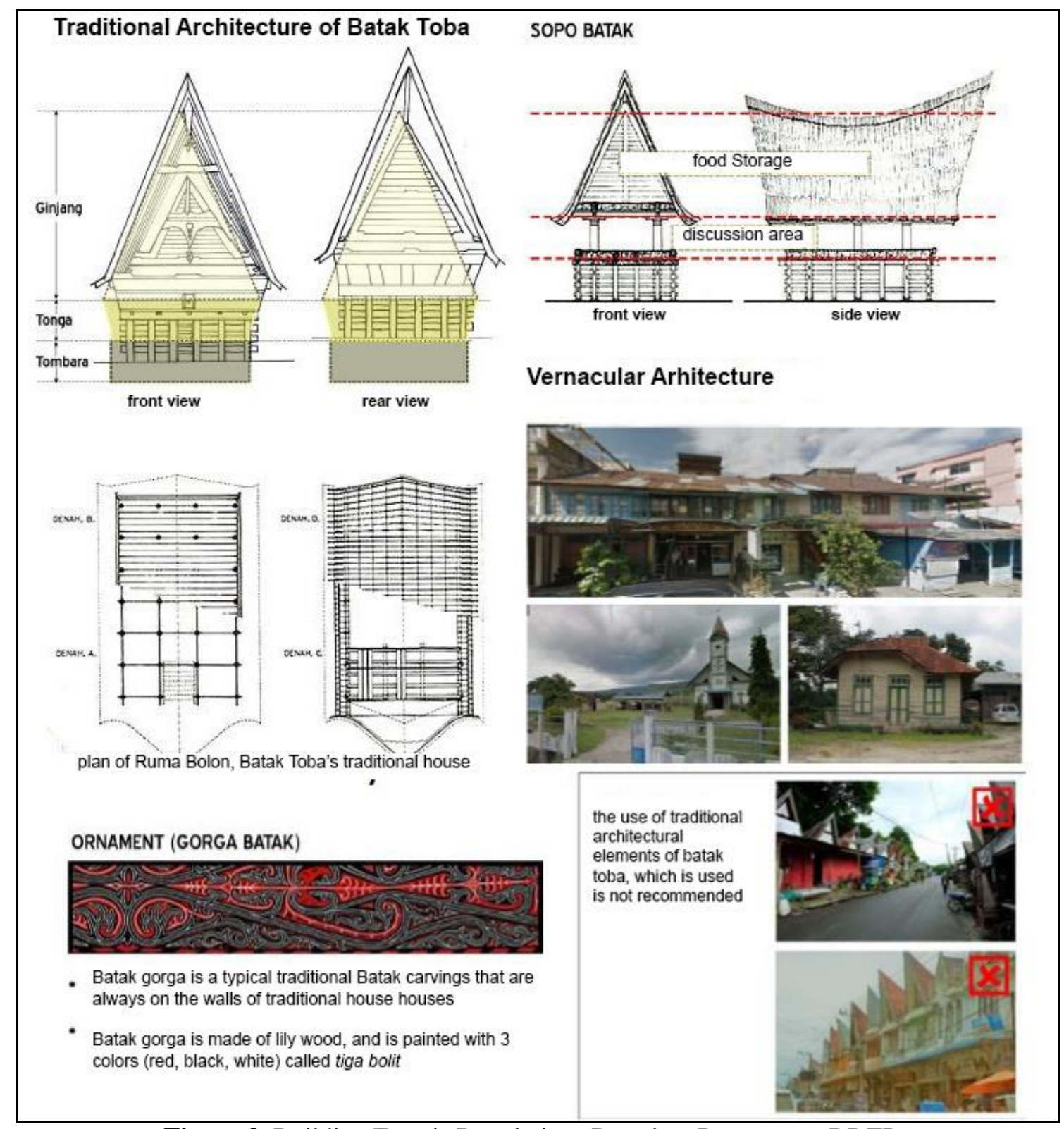

Figure 3. Building Facade Regulations Based on Pangururan RDTR. Source: Pangururan's RDTR 2017

\section{Basic Concept of Design}

The basic concept is the design of Samosir Ulos Weaving Craft Center formed through the Metaphoric Architecture theme that takes through the tangible Metaphor type, which the physical form of the Batak customary process where the Ulos hang to a bride during the Batak traditional wedding process. 


\section{Mass-Shaped Concept}

Building mass through the application of themes that adapt the form of Ulos and the bride. The adaptation of the metaphor used in this building is using a tangible metaphor (Figure 4).

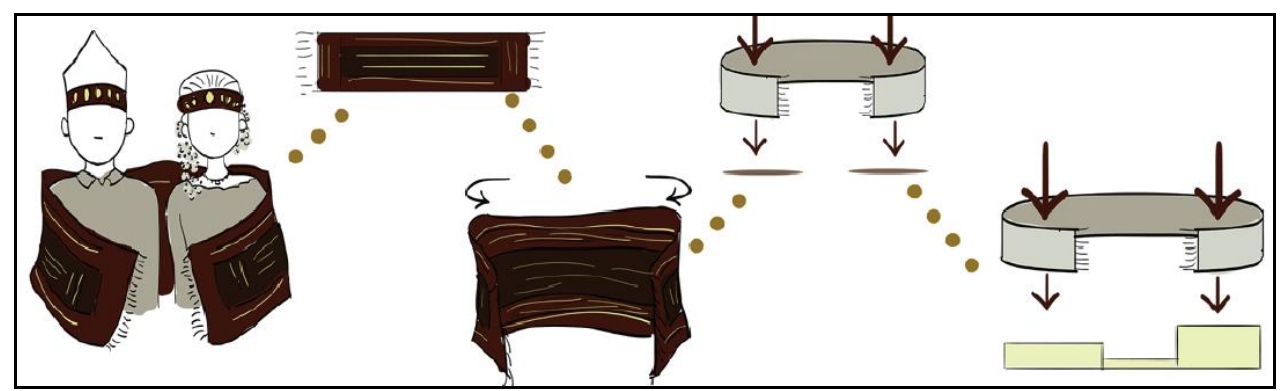

Figure 4. Metaphorical Concept of Building Mass.

There is two part of the formation of the building with the one wide inner-court among with the building. This symbolizes the procession of Mangulosi using the logic of the 3-story building as the bridegroom's figure and the 2 -story building as the bride. And the secondary skin shading that forms an Ulos cloth wraps the building (Figure 5).

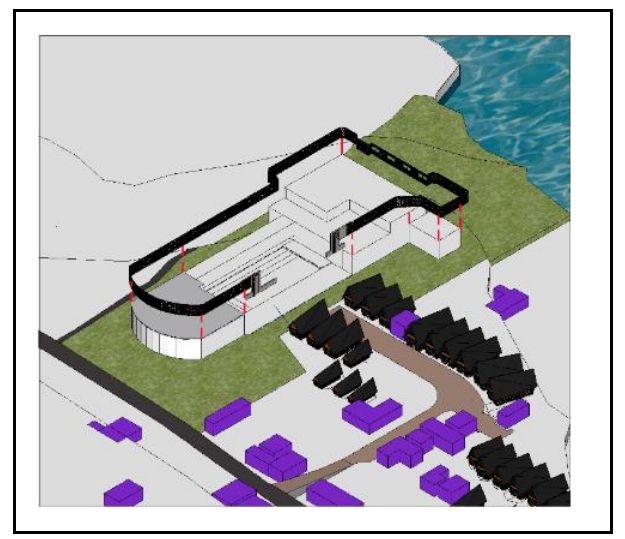

Figure 5. The form of mass and secondary skin of buildings.

The concept of mass composition is also formed with two building masses side by side with inner-court between them. The mass of the building shaped into 2 masses with different height levels symbolizes a pair of brides side by side with a shrouded secondary skin with a rectangular pattern of Ulos Sadum shaped around the mass of the building, a sky bridge with a veil of Ulos' pattern representing Ulos cloth as a binder between the bride and groom (Figure 6). 


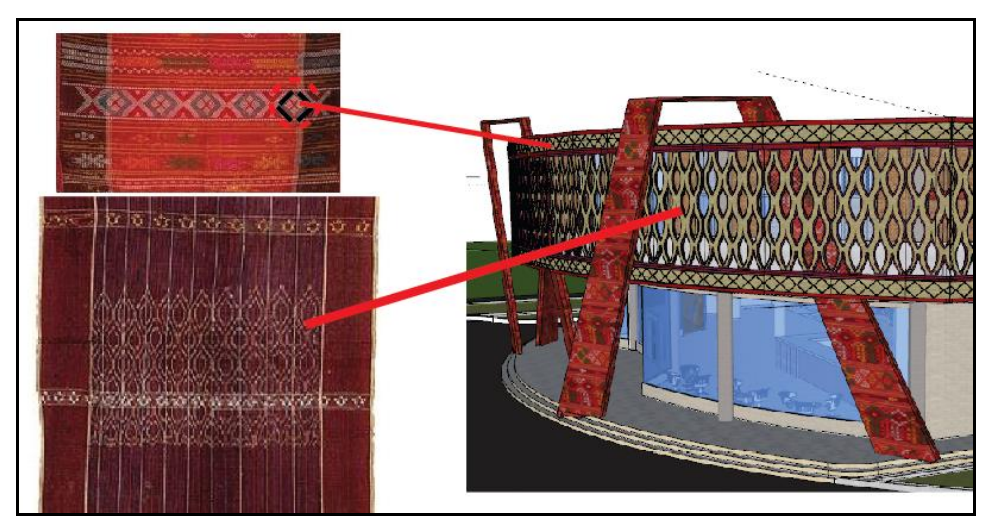

Figure 6. The Concept of Building Secondary Skin.

Secondary skin made around the building symbolizes the enveloping Ulos cloth, and the modified Ulos Sadum and Bintang Maratur reflect the Batak tribal culture, which means happiness to fulfill the 2017 RDTR rules as an image of local wisdom. The form of mass face to face in the workshop area will give effect to the typical Toba Batak village atmosphere, where every house is always facing the open courtyard among it and confirms the main orientation of the building in the workshop area.

\section{The Concept of Outer Space}

The endemic plant of Samosir Island, such as the Si Paet-Paet Flower, and the Flamboyant Flower plants at the location of the outdoor design space. In addition to Vegetation, open spaces in buildings especially on the edge of the lake adds a promenade as a leisure area and a plaza for visitors to the building and it is useful as a lake water barrier that often rises above the water surface and also follows the completeness of the function of the building as a recommended tourist zone of the community equipped with promenades, plazas, and pedestrians (Figure 7).

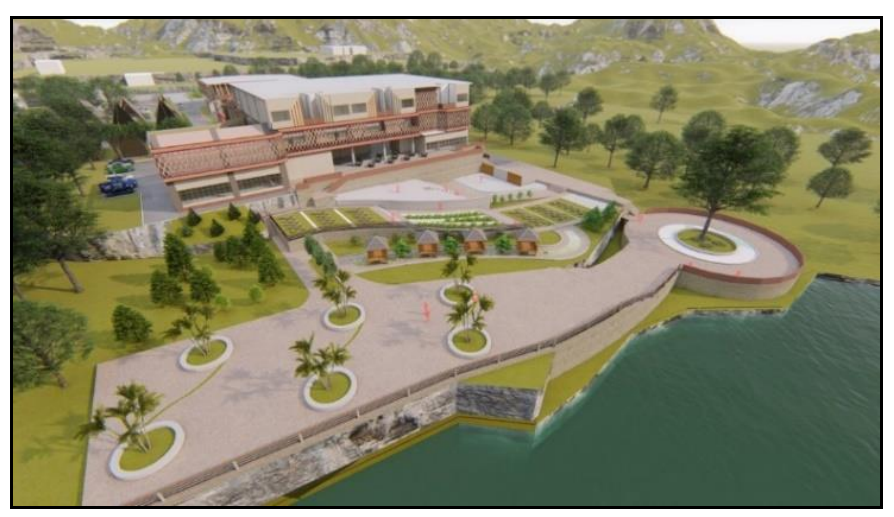

Figure 7. The Concept of Open Space and Promenade.

By the lakeside regulations of the RDTR in Pangururan sub-district in 2017 to decorate the community area of the community with a waterfront area equipped with pedestrian circulation (Figure 8). And in the mass arrangement of the building and zoning of at the design location of 
the promenade and the open space is placed behind the building and the parking area on the side of the building (Figure 9).

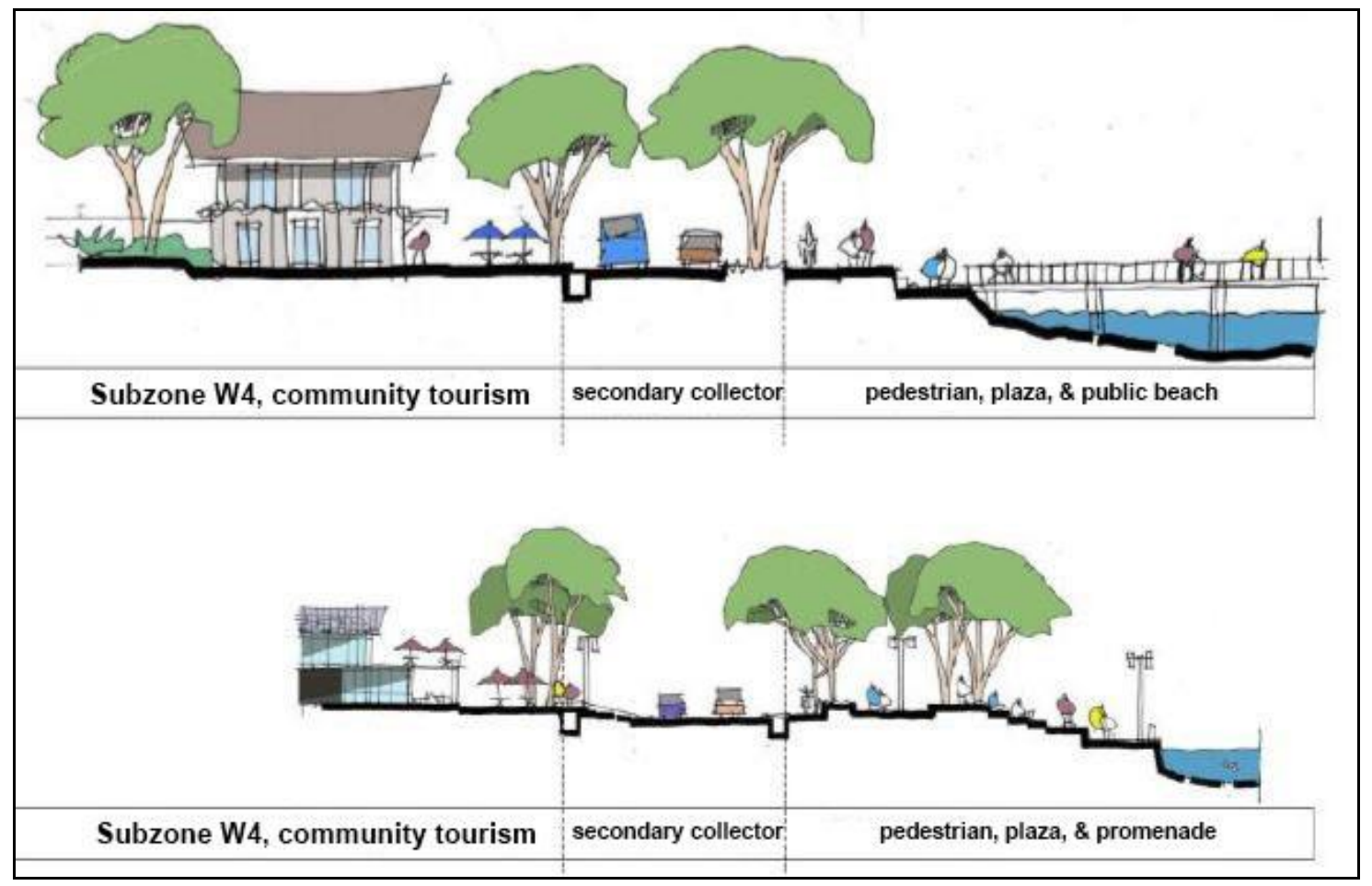

Figure 8. The Regulation of The Lakeside Space According to The Pangururan's RDTR. Source: Pangururan's RDTR 2017

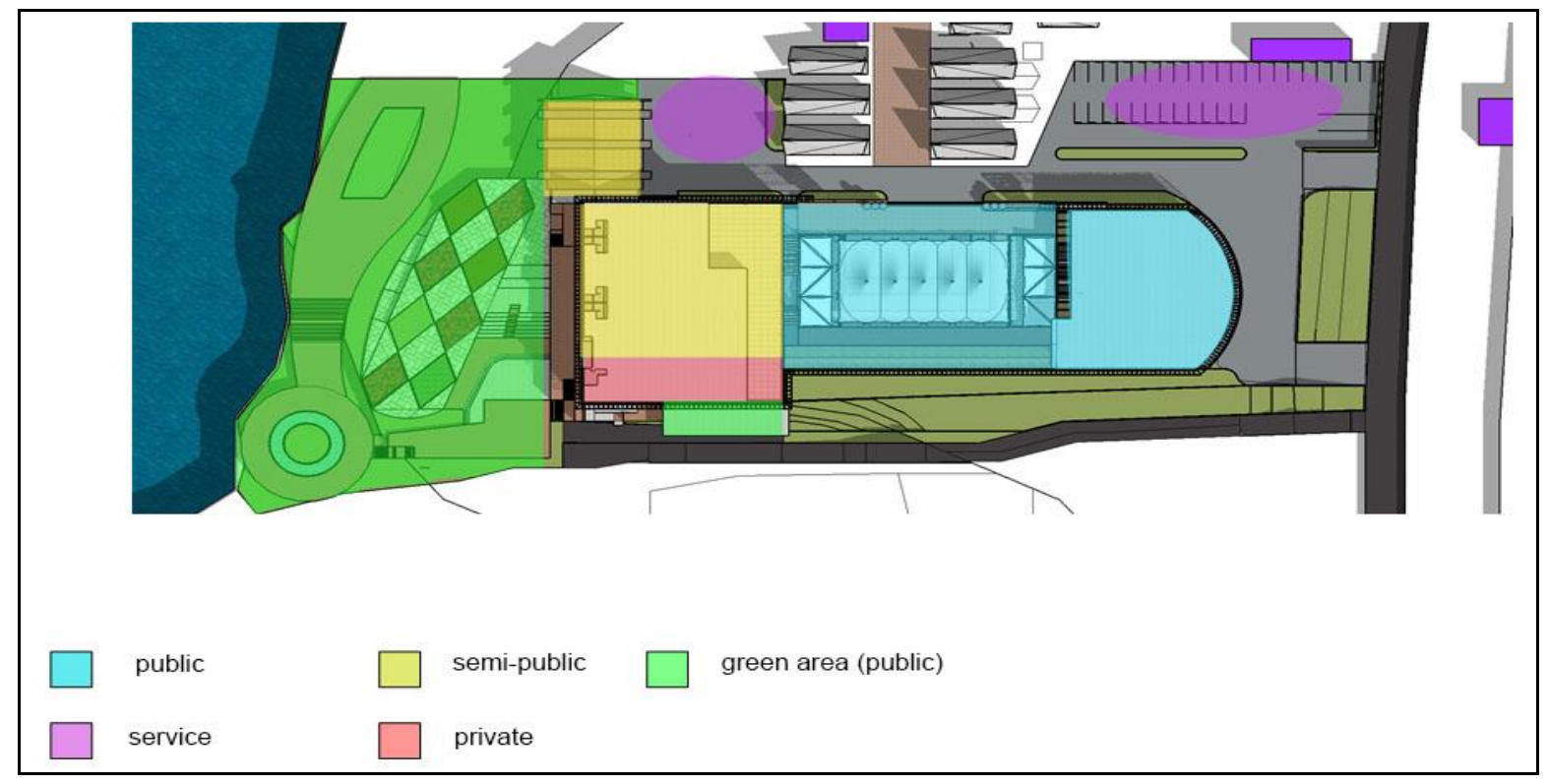

Figure 9. Space Zoning In the Site Design 


\section{Inner Space Concept}

The building will forms into three main interior spaces, including the Exhibition building and souvenir shop, which is the area that will receive visitors for the first time. Then the middle part is an amphitheater that is quite wide, which is an area of Mangulosi craftsmen outside the room. Then the third part is the indoor workshop, multipurpose room, and homestay services.

One of the main spaces presented in this building is the Batak Ulos gallery. This room is in the front area of the building because it is one of the primary functions of this building by displaying Ulos works from all over North Sumatra. On the level of privacy, this room is classified as semi-public because to enter the room must buy an entrance ticket.

The gallery space is designed to be closed and calm so that visitors who come are more focused on the objects on display. A variety of linear and diffuse combinations shapes the design of the gallery circulation with the exhibited items placed on the edge and center. The circulation of Ulos galleries also directs visitors to the workshop area in the middle of the building (Figure $10)$.

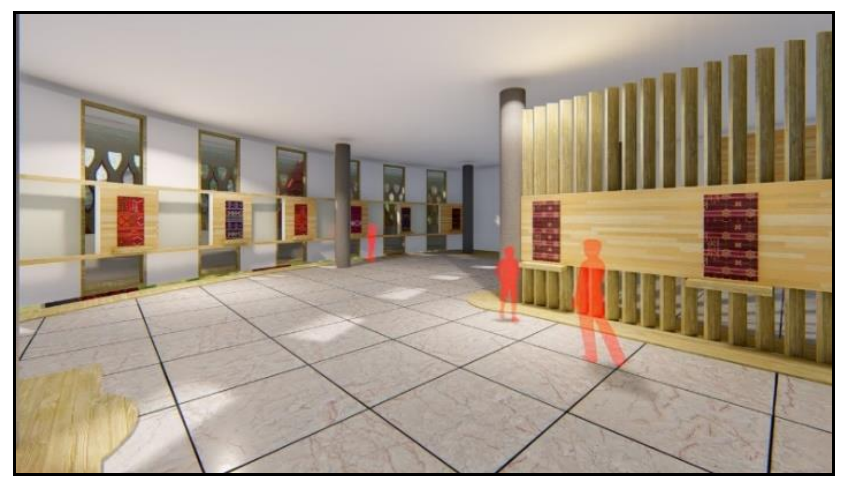

Figure 10. The Interior Concept of the Exhibition Hall

The workshop is one of the main functions of the building. The workshop area will show a demonstration and the process of making Ulos weaving from beginning to end. The workshop area is in the middle of a building with the nature of semi-public space. There are two types of workshop area on this building, namely open workshops and closed workshops (Figure 11).

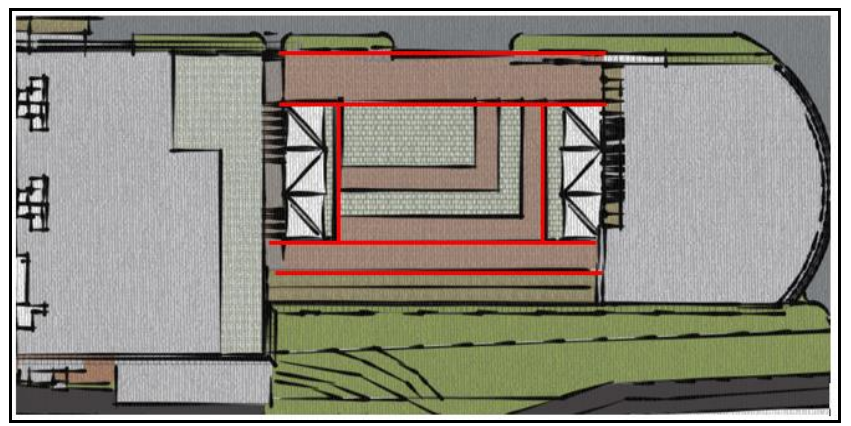


Figure 11. Outdoor Workshop Space Concept

This outdoor workshop is covered by a tent structure as shading from direct sunlight because, in dry weather, the level of the sunlight in the Samosir area is quite hot. The floor on the area of the outdoor workshop itself shapes as the basic pattern of an Ulos. T.M. Sihombing interprets there are three main meanings (Tripartition) in the Ulos section of the Toba Batak, especially in the life type, that is, on the left and right sides of each area describes the area of rice fields where farming is one of the sources of life. The middle part is depicted the sun and rain that support the surface of the earth. And on the part of the head/foot is life [10] (Figure 12).

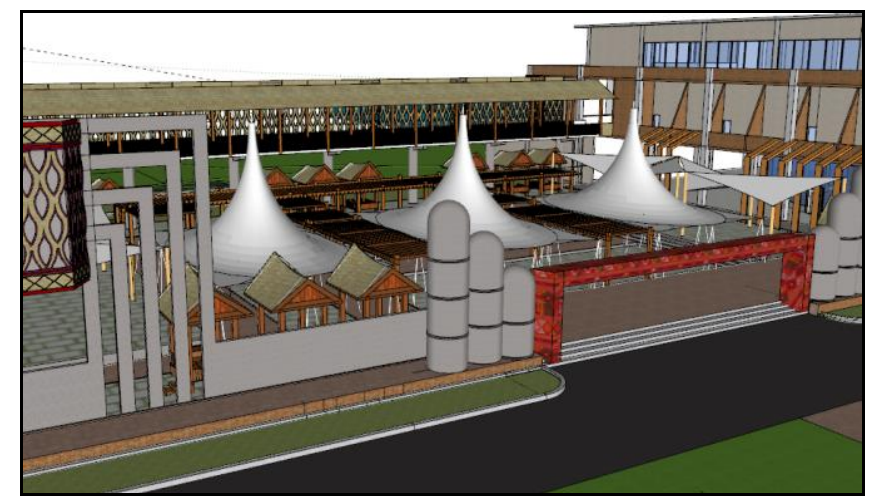

Figure 12. Outdoor Workshop Space Perspective

Whereas in the indoor workshop area is used to show the process of making of the modern Ulos and also using machines. The homestay in the building is on the back side of the building, facing Lake Toba, where the visitors can stay in several types of room. In the homestay area, there is a communal space between rooms so that visitors can gather together like the Batak community culture that likes to.

\section{Conclusion}

The design of Ulos Samosir Weaving Craft Center located on Jl. Gereja, Lumban Suhi-Suhi Toruan Village, Pangururan District, Samosir Regency is a place for Ulos weavers to produce Ulos and maintain their sustainability, and also educate the people of Indonesia and abroad. The building function is as an Ulos weaving exhibition gallery, Ulos weaving workshop, and also as a homestay for tourists who stay or hold a study tour. Ulos Samosir Weaving Craft Center presents a new educational and cultural and natural recreation facility in the Samosir area.

Using the theme of metaphoric architecture with the type of Tangible Metaphor, the design of Ulos Samosir Weaving Craft Center concept takes the form of an event of bride Batak Mangulosi which forms a building with two masses that are unite by a building secondary skins that forms an Ulos cloth, so that the building looks like an Ulos cloth covering two brides. The Ulos Sadum and the Bintang Maratur Ulos pattern, which symbolizes happiness, inspire the formation of secondary skin. In the middle of the building, there is an outdoor workshop area 
that looks at the condition of the traditional Samosir people who weave Ulos in their yard, and the outdoor workshop area forms an Ulos pattern consisting of the right and left sides, head, feet, and body.

\section{Acknowledgment}

The author thanks God for the blessings given so that this journal can be completed properly. The author also thanked the Department of Architecture, The University of Sumatra Utara, for guiding and assisting well in the administration and research process.

\section{REFERENCES}

[1] M. Takari, "Ulos dan Sejenisnya Dalam Budaya Batak Di Sumatera Utara: Makna, Fungsi, dan Teknologi," in Seminar Antarbangsa Tenunan Nusantara, Kuantan, Pahang, Malaysia, 2009.

[2] Kemendikbud. [Online]. Available: https://kbbi.kemendikbu.go.id/entri/metafora. [Accessed March 2018].

[3] S. K. Koca and U. Oze, "How Does Concept Transform Into Product? An Appraisal of Analogybased Design Practices In Architecture Education," in Procediasocial and Behavioural Sciences, Turkey, 2014.

[4] K. K. W. Neo, "Metaphor As A Conceptual Tool In Design," in 44th Annual Conference of The Architectural Science Association, Singapore: Nanyang Academy of FIne Arts, 2010.

[5] S. K, J. C. Anthony and J. Catanese, Introduction of Architecture, USA: Mc Graw-Hill, Inc, 1979.

[6] C. Jenks, The Language of Post-Modern Architecture, Detroit: Rizolli, 1984.

[7] A. C. Antoniades, The Poetics of Architecture: Theory of Design, New York: Razolli, 1992.

[8] A. C. Barus, M. Simanjuntak and F. Panjaitan, "Cultural Innovation of Ulos Pattern Heritage as Creative Campaign to Promote Tourism in Toba Highland," Creative, Strategy, Innovation, and Policy Making for Heritage and Cultural Landscape, vol. Track C, pp. 537$547,2015$.

[9] Badan Pusat Statistik Kabupaten Samosir, "Kecamatan Pangururan Dalam Angka," BPS Kabupaten Samosir, Samosir, 2017.

[10] G. Rudiyanto, "Ulos: Ragam Hias dan Maknanya Dalam Kehidupan Masyarakat Batak Toba," Dimensi, Trisakti, vol. III, 2005. 